\title{
Distribution of carboxyhaemoglobin concentrations in smokers and non-smokers
}

\author{
JA McM TURNER, MW McNICOL, RW SILLETT \\ From the Department of Thoracic Medicine, Central Middlesex Hospital, and the Department of Medicine, \\ Middlesex Hospital Medical School, London
}

ABSTRACT Carboxyhaemoglobin concentrations were measured in 3487 subjects comprising 1255 non-smokers, 1933 cigarette smokers, 193 cigar smokers (39 primary, 154 secondary), and 106 pipe smokers (30 primary, 76 secondary). In cigarette smokers the mean carboxyhaemoglobin concentration was $4.78 \%$ of the total haemoglobin and $94.7 \%$ of smokers had a concentration greater than $1.7 \%$. Primary cigar smokers had a much lower mean carboxyhaemoglobin concentration $(0.93 \%)$, and only $10.3 \%$ had concentrations greater than $1.7 \%$. Primary pipe smokers also had a low mean carboxyhaemoglobin concentration $(1.36 \%)$ and none had a concentration above $1.7 \%$. Secondary cigar smokers had a high mean concentration $(6.80 \%)$ and $97.4 \%$ had values above $1.7 \%$; the findings in secondary pipe smokers were similar-the mean concentration was $3.39 \%, 94.7 \%$ having values greater than $1.7 \%$. The lower carboxyhaemoglobin concentrations in primary pipe and cigar smokers suggest that in general they do not inhale, and the raised concentrations in cigarette smokers who change to pipes or cigars suggest that they usually continue to inhale and to absorb large amounts of carbon monoxide and other constituents of tobacco smoke.

The carboxyhaemoglobin concentration in the blood has been shown to be an accurate marker of tobacco smoke inhalation, ${ }^{1-6}$ but there is less information about the effect of different types of smoking. ${ }^{7-10} \mathrm{We}$ have previously shown in detailed studies on a small group of subjects that primary cigar and pipe smokers have low carboxyhaemoglobin and nicotine concentrations after smoking cigars or pipes, whereas secondary cigar or pipe smokers have raised concentrations. $^{811}$ In this paper we extend these observations, reporting the results of 3487 determinations of carboxyhaemoglobin concentrations obtained in our laboratory from subjects for whom a detailed smoking history was available.

\section{Methods}

Venous blood samples were taken during the morning from members of staff, inpatients and outpatients at Central Middlesex Hospital over five years. No restriction was placed on smoking before sampling, and no attempt was made to determine the interval

\footnotetext{
Address for reprint requests: Dr JA McM Turner, Royal National Hospital, Bournemouth BH2 6DN.
}

Accepted 9 September 1985 between smoking and blood sampling. At the time of sampling a detailed smoking history was taken. In cigar and pipe smokers particular care was taken to differentiate between primary cigar and pipe smokers and those who had previously been regular cigarette smokers. Primary pipe and cigar smokers were defined as subjects who had smoked less than one cigarette a day for one year.

Samples were stored at $4^{\circ} \mathrm{C}$ and were analysed in batches. Measurements were made in duplicate with an IL182 CO Oximeter, which was fully calibrated before each batch of measurements. ${ }^{12}$

\section{Results}

Table 1 shows the distribution of carboxyhaemoglobin concentrations. The lowest concentrations were seen in the primary cigar smokers (mean $0.93 \%$ of total haemoglobin, range $0.3-2.2 \%$ ) and primary pipe smokers (mean $1.36 \%$, range $0.8-1.6 \%)$. The highest carboxyhaemoglobin concentrations were seen in secondary cigar smokers (mean $6.8 \%$, range $0.9-14.7 \%$ ). The secondary pipe smokers had rather lower concentrations (mean 3.39\%, range $0.5-8.3 \%)$. The highest individual concentrations were found in cigarette smokers (mean $4.8 \%$, range $0.4-16.7 \%)$. 
Table 1 Carboxyhaemoglobin concentrations in non-smokers, cigarette smokers, and primary and secondary cigar and pipe smokers

\begin{tabular}{|c|c|c|c|}
\hline & \multicolumn{3}{|c|}{$\mathrm{CoHb}(\%$ total haemoglobin) } \\
\hline & $n$ & $\begin{array}{l}\text { Mean } \\
(S D)\end{array}$ & Range \\
\hline $\begin{array}{l}\text { Non-smokers } \\
\text { Cigarette smokers }\end{array}$ & $\begin{array}{l}1255 \\
1933\end{array}$ & $\begin{array}{l}0.91(0.37) \\
4.78(2.67)\end{array}$ & $\begin{array}{l}0.1-1.7 \\
0.4-16.7\end{array}$ \\
\hline $\begin{array}{l}\text { Cigar smokers } \\
\text { Primary } \\
\text { Secondary }\end{array}$ & $\begin{array}{r}39 \\
154\end{array}$ & $\begin{array}{l}0.93(0.53) \\
6.80(3.00)\end{array}$ & $\begin{array}{l}0.3-2.2 \\
0.9-14.7\end{array}$ \\
\hline $\begin{array}{l}\text { Pipe smokers } \\
\text { Primary } \\
\text { Secondary }\end{array}$ & $\begin{array}{l}30 \\
76\end{array}$ & $\begin{array}{l}1.36(0.18) \\
3.39(1.74)\end{array}$ & $\begin{array}{l}0.8-1.6 \\
0.5-8.3\end{array}$ \\
\hline
\end{tabular}

Table 2 classifies the subjects into two groupsthose with carboxyhaemoglobin concentrations above $1.7 \%$ and up to $1.7 \%$, the value we have previously found to be the upper limit of normal in our laboratory. ${ }^{11}$ Concentrations above normal were found in none of the primary pipe smokers and only $10.3 \%$ of the primary cigar smokers but in $94.7 \%$ of cigarette smokers, $\mathbf{9 7 . 4 \%}$ of secondary cigar smokers, and $94.7 \%$ of secondary pipe smokers.

\section{Discussion}

The accuracy of the smoking history is clearly crucial in differentiating between primary and secondary smokers of cigars or pipes. While smokers often underreport the number of cigarettes they smoke, ${ }^{12}$ there is no evidence that they report inaccurately the types of smoki $\mathrm{g}$ materials that they use. Our smoking histories were taken by experienced observers and recorded at the time of blood sampling. We believe that they identify accurately as primary pipe and cigar smokers individuals who have never previously used cigarettes.

These findings in a much larger number of subjects confirm our earlier observation that primary cigar and pipe smokers do not inhale and thus do not absorb carbon monoxide or other smoke constituents. The association between raised carboxyhaemoglobin

Table 2 Numbers of smokers with normal and raised carboxyhaemoglobin $(\mathrm{CoHb})$ concentrations

\begin{tabular}{lrlll}
\hline & $n$ & \multicolumn{3}{l}{$\mathrm{CoHb}$} \\
\cline { 3 - 5 } & & $\begin{array}{l}\text { Normal } \\
(\leqslant 1.7 \%)\end{array}$ & $\begin{array}{l}\text { Raised } \\
(>1.7 \%)\end{array}$ & $\%$ raised \\
\hline Cigarette smokers & 1933 & 102 & 1831 & 94.7 \\
$\begin{array}{l}\text { Cigar smokers } \\
\begin{array}{l}\text { Primary } \\
\text { Secondary }\end{array}\end{array}$ & 39 & 35 & 4 & 10.3 \\
$\begin{array}{l}\text { Pipe smokers } \\
\quad \text { Primary }\end{array}$ & 30 & 4 & 150 & 97.4 \\
$\quad$ Secondary & 76 & 30 & 0 & 0 \\
\hline
\end{tabular}

concentrations and cigarette smoking is striking, as is its persistence in cigarette smokers who have changed to cigars or pipes. Unlike primary cigar or pipe smokers, who do not inhale, most secondary pipe or cigar smokers treat these materials as cigarettes and continue to inhale. ${ }^{81011}$

The upper limit of normal for carboxyhaemoglobin used in our laboratory $(1.7 \%)$ clearly distinguishes between cigarette smokers and non-smokers. The same concentration also largely distinguished between primary and secondary cigar and pipe smokers, in $97.4 \%$ and $94.7 \%$ of whom the concentrations were abnormal. None of the primary pipe smokers had raised carboxyhaemoglobin and only $10.3 \%$ of the primary cigar smokers had a raised concentration. This confirms our previous findings in primary cigar and pipe smokers. ${ }^{811}$

Wald ${ }^{13}$ reported similar findings and suggested the use of a slightly higher upper limit of normal for carboxyhaemoglobin $(2 \%)$, but found a rather poorer discrimination, identifying only $81 \%$ of cigarette smokers by this criterion. ${ }^{4}$ Whichever upper limit of normal is used, abnormally raised concentrations indicate abnormal exposure to carbon monoxide, which is most likely to come from smoking and is almost certainly indicative of past or present cigarette smoking.

A change from cigarettes to other smoking materials appears to confer no benefit from reduced inhalation. The highest mean carboxyhaemoglobin concentrations were found in secondary cigar smokers and the proportion of secondary pipe and cigar smokers with raised concentrations was similar to that of cigarette smokers. These results confirm the importance of cigarette smoking in setting the pattern of inhalation. Most primary pipe and cigar smokers inhale minimally, but most of those who have regularly smoked cigarettes inhale and continue to do so whatever smoking material they use.

\section{References}

1 Russell MAH, Wilson C, Cole PV, Idle M, Feyerabend C. Comparison of increase in carboxyhaemoglobin after smoking extra mild and non mild cigarettes. Lancet 1973;ii:687-90.

2 Russell MAH, Cole PV, Idle M, Adams L. Carbon monoxide yields of cigarettes and their relation to nicotine yield and type of filter. $\mathrm{Br}$ Med J 1975;ii:71-3.

3 Wald NJ, Idle M, Bailey A. Carboxyhaemoglobin levels and inhaling habits in cigarette smokers. Thorax 1978;33:201-6.

4 Wald NJ, Idle M, Boreham J, Bailey A. Carbon monoxide in breath in relation to smoking and carboxyhaemoglobin levels. Thorax 1981;36:366-9.

5 Ashton H, Stepney R, Thompson JW. Should intake of carbon monoxide be used as a guide to intake of other smoke constituents? Br Med J 1981;282:10-3. 
6 Salooje Y, Vesey CJ, Cole PV, Russell MAH. Carboxyhaemoglobin and plasma thiocyanate: complementary indicators of smoking behaviour. Thorax 1982;37:521-5.

7 Wald NJ, Idle M, Boreham J, Bailey A, van Vunakis $\mathbf{H}$. Serum cotinine levels in pipe smokers: evidence against nicotine as a cause of coronary heart disease. Lancet 1981;ii:775-7.

8 Turner JA McM, Sillett RW, McNicol MW. The effect of cigar smoking on carboxyhaemoglobin and plasma nicotine concentrations in primary pipe and cigar smokers and ex-cigarette smokers. Br Med J 1977;ii:1387-9.
9 Jarvis MJ. Russell MAH. Nicotine, carbon monoxide and heart disease. Lancet 1981;ii:1044.

10 McCusker K, McNab E, Bone R. Plasma nicotine levels in pipe smokers. $J A M A$ 1982;248:577-8.

11 Turner JAMcM, Sillett RW, McNicol MW. The inhaling habits of pipe smokers. Br J Dis Chest 1981;75:71-6.

12 Sillet RW, Wilson MB, Malcolm RE, Ball KP. Deception among smokers. $\mathrm{Br}$ Med $J$ 1978;ii:1185-6.

13 Wald NJ, Idle M, Boreham J, Bailey A, van Vunakis H. Nicotine, carbon monoxide and heart disease. Lancet 1982;i:40-1. 